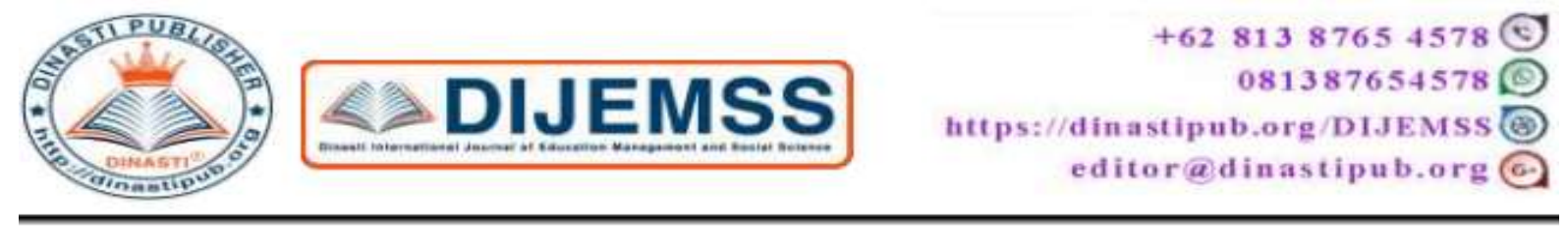

\title{
POSTMODERNISM AND THE RELATIONSHIP OF THE IMPLEMENTATION GOOD CORPORATE GOVERNANCE
}

\section{Syahrian}

STIE Trisakti, Jakarta, Indonesia

Email: syahrian2014@gmail.com

\section{ARTICLE INFORMATION}

Received: 19 December 2019

Revised: 24 December 2019

Issued: 25 December 2019

Corresponding author: first author E-mail: syahrian2014@gmail.com

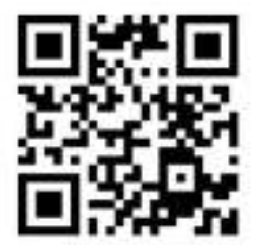

DOI:10.31933/DIJMESS
Abstract: Postmodernism, a reality that is beginning to have a strong influence on the lives of individuals and groups, is no exception in the management of organizations, particularly good corporate governance (GCG). This understanding has led to pessimism and apathy toward the increasingly uncontrollable passion of life, as a result of thoughts that no longer believe in absolute truth and objective and rational standards. This paper further reveals the implications of postmodernism on ethics, proxy war, and optimizing the application of GCG in government organizations. The results of the in-depth study concluded that postmodernization was entrenched in the lives of both individuals and groups, doing what was right in their own view (group), reduced trust in community diversity, pluralism, relativism, information overload, high mobility, identity confusion, consumerism and etc. Ethics has been eliminated and the proxy war is out of control. Proxy war as an arm of a country that seeks to get its strategic interests in a particular country. Proxy war has taken place in various forms, especially in Indonesia, such as ethics in the use of the internet.

Keywords: Postmodernism, Proxy War, Ethics, Corporate Governance

\section{INTRODUCTION}

Nearly a century ago, the phrase "magical American first" was uttered by Franklin D. Roosevelt, in his first inauguration as US president, even though the situation, political and economic, was very different. America and the world, in 1933, were ruins after the Great Depression, when the economy experienced a deep contraction, inflation skyrocketed, industry went bankrupt and ethics was torn. Roosevelt did not start with an economic pressure point, but ethics. In an interdependent economic system, protective attitude will suppress the potential for economic growth. International trade is a dominant element in 
growth. Barriers to immigrant workers from Mexico, for example, will directly increase production costs. Don't forget, Mexico is the biggest market for US products. A trade war between two of the world's biggest economic powers will not only harm the US and China, but also the global economy, including Indonesia.

The current Tax Amnesty program carried out by the Indonesian government contains more controversy, calling it tax as a means of income distribution or tax reduction will widen the prosperity gap. Though one Indonesia's problem is widening the income gap. One of the gaps that occurs in America is that there are similarities in Indonesia. However, as in Indonesia, budget constraints are a common obstacle faced by many countries in efforts to spur and accelerate infrastructure development. In addition, the time lag between increasing infrastructure spending and its impact on economic growth is quite long, as exemplified by China and India.

Some trade reforms introduced in early 2016 indicate important changes in the direction of trade policy, which could help reduce food price inflation. The high level of bank interest rates in Indonesia. Fiscal policy can reduce inequality. Funds from the reallocation of fuel subsidies carried out in 2015 have helped, but there are many other actions that can support the handling of inequality. The challenge to revive the industrial competitiveness of Indonesia's manufacturing sector.

The widespread phenomenon of proxy war, postmodernism, business ethics and good governance for organizations lately, shows that it is still unclear, the link between postmodernism, proxy war, business ethics and the optimization of the application of the principles of Good Corporate Governance in Indonesia. This paper will reveal the implications of postmodernism for proxy war, business ethics and the optimization of the application of the principles of Good Corporate Governance in Indonesia.

\section{LITERATURE REVIEW \\ Postmodernism}

Etymologically Postmodernism, derived from English which means understanding (ism) that developed after (post) modern. This term first appeared in 1930 in the arts by Federico de Onis to show the reaction of modernism. Then in the field of History by Toyn Bee in his book Study of History in 1947. After that it developed in other fields and brought criticism of modernism in its own fields. Postmodernism is distinguished from postmodernity.

If postmodernism refers more to the concept of thinking, postmodernity refers more to the situation and social order of information technology products, globalization, lifestyle fragmentation, excessive consumerism, deregulation of financial markets and public facilities, obsolete state and nation, and the exploration of traditional inspiration. This briefly actually wants to appreciate other factors (tradition, spirituality) which are removed by rationalism, structuralism, and secularism.

The 20th century can be divided into two different periods, one marked by the modernism movement and the other with postmodernism. Postmodernization is sometimes called postmodenisation or often abbreviated as PostMo, a concept that rejects modern tendencies that place boundaries between certain things such as academic discipline, culture and life, fiction and theory, image and reality. Postmodernism is considered a response to modernism and therefore both are two aspects of the same movement.

There are several main differences between modernism and postmodernism, namely in the way of approach to life. Modernism represented various cultural movements in the late 19 th and early 20 th centuries. Modernism includes reform movements in art, reading, music, 
architecture and applied arts. This movement is also marked by efforts to involve science and technology in every aspect of life. Modernism brought reforms in all fields of life including philosophy, trade, art, and literature with the help of technology.

Table 1. Growth of PreModernism, Modernism, and Postmodernism

\begin{tabular}{|c|c|c|c|}
\hline & $\begin{array}{l}\text { Premodernism } \\
1000 \text { BC-1450 }\end{array}$ & $\begin{array}{l}\text { Modernism } \\
1450-1960\end{array}$ & $\begin{array}{l}\text { Postmodernism } \\
1960 \text { - }\end{array}$ \\
\hline Production & $\begin{array}{l}\text { Neolithic Revolution } \\
\text { Agriculture } \\
\text { Handwork } \\
\text { Dispersed } \\
\end{array}$ & $\begin{array}{l}\text { Industrialis } \\
\text { Factory } \quad \text { mass-production } \\
\text { centralised }\end{array}$ & Information Revolution \\
\hline Society & $\begin{array}{l}\text { Tribal/Feudal } \\
\text { Ruling class of King, Priests \& } \\
\text { Military Peasnts }\end{array}$ & $\begin{array}{l}\text { Capitalis } \\
\text { Owning class bourgeoisie } \\
\text { workers }\end{array}$ & Global \\
\hline Time & Slow-Changing reversible & Linear & Fast-changing cyclical \\
\hline Orientation & $\begin{array}{l}\text { Local/City } \\
\text { Agrarian }\end{array}$ & $\begin{array}{l}\text { Nationalist } \\
\text { Rationalisation of business } \\
\text { exclusive }\end{array}$ & $\begin{array}{l}\text { World/Local } \\
\text { Multinational } \\
\text { Fluralis } \\
\text { Eclectic } \\
\text { Inclusive }\end{array}$ \\
\hline Culture & $\begin{array}{l}\text { Aristocratic } \\
\text { Integrated style }\end{array}$ & $\begin{array}{l}\text { Bourgeois } \\
\text { Mass-culture reigning styles }\end{array}$ & $\begin{array}{l}\text { Taste-cultures } \\
\text { Many Genres }\end{array}$ \\
\hline
\end{tabular}

Postmodernism means, 'after modernism'. This movement was a reaction to modernism which was influenced by the disappointment caused by World War II. Postmodernism refers to circumstances that do not have a central hierarchy, are ambiguous, and diverse. Developments in society, economy, and culture in the 1960s were strongly influenced by postmodernism. In other words, our current condition has gone beyond modernism and has entered into postmodernism.

Table 2. Defining PreModernism, Modernism, and Postmodernism

\begin{tabular}{|l|l|l|l|}
\hline & \multicolumn{1}{|c|}{ PreModernism } & \multicolumn{1}{c|}{ Modernism } & \multicolumn{1}{c|}{ Postmodernism } \\
\hline Metaphysics & Realism: Supernaturalism & $\begin{array}{l}\text { Realism: } \\
\text { Naturalism }\end{array}$ & Anti Realism \\
\hline Epistemology & Mystism and/or faith & $\begin{array}{l}\text { Objectism: } \\
\text { Experience dan Reason }\end{array}$ & Sosial Subjectivism \\
\hline Human Natural & $\begin{array}{l}\text { Original Sin; Subject to God's } \\
\text { Will }\end{array}$ & Tabula rasa and authonomy & $\begin{array}{l}\text { Social construction and } \\
\text { conflict }\end{array}$ \\
\hline Ethics & Collectivism: altruism & Individualism & Collectivism: egalitarianism \\
\hline Politics \& Economics & Feudalism & Liberal capitalism & Socialism \\
\hline When \& Where & Medieval & $\begin{array}{l}\text { The Enlightenmen; } 20^{\text {th }} \\
\text { Century sciences, business, } \\
\text { and technical fields }\end{array}$ & $\begin{array}{l}\text { Lated twentieth century } \\
\text { humanities and related } \\
\text { proffesions }\end{array}$ \\
\hline
\end{tabular}

This postmodern understanding is embraced by certain individuals or groups or communities, which began to move in the late 20th century in art, architecture, and criticism, which continued modernism (Reichl, 1989). Post-modernism or Postmodernism is a skeptical interpretation of culture, literature, art, philosophy, history, economics, architecture, fiction, and literary criticism, so that it is often associated with deconstruction and poststructuralism, because its use as a term gained significant popularity at the same time as post-structuralism, that is, in the twentieth century.

Postmodernism is a concept that developed after the modern era with its modernism. Postmodernism is not a single understanding or a theory, but rather an umbrella for various theories that are scattered and difficult to find a single common ground. Many figures give Postmodernism meaning as a continuation of modernism. But the sequel became very diverse. For Lyotard and Geldner, postmodernism is a total break from modernism. For Derrida, Foucault and Baudrillard, Postmodernism is a radical form of modernity that eventually "dies alone" because of the difficulty of uniforming various theories. For David 
Graffin, Postmodernism is a correction of some aspects of modernism. In addition, for Giddens Postmodernism is a form of modernism that is self-aware and wise. Another view, namely Habermas, postmodernism is an unfinished stage of modernism.

Tabel 3. Relative Emphases in Modernism and Postmodernism

\begin{tabular}{|c|c|}
\hline Modernist emphasis & Postmodern emphasis \\
\hline Object & Image, symbol \\
\hline Cartesian subject & Symbolic subject \\
\hline Cognitive subject & Semiotic subject \\
\hline Unified subject & Fragmented subject \\
\hline Centered subject & Decentered subject \\
\hline Signified & Signifier \\
\hline Objectification & Symbolization \\
\hline Representation & Signification \\
\hline Truth (objective) & Truth (constructed) \\
\hline Real & Hyperreal \\
\hline Universalism & Localism, particularism \\
\hline Society as a structure & Society as a spectacle \\
\hline Logocentric reason & Hermeneutic reason \\
\hline Knowing & Communicating \\
\hline Economy & Culture \\
\hline Capitalism & Late capitalism \\
\hline Economic systems & Symbolic systems \\
\hline Production & Consumption \\
\hline Shift from use value to exchange value & Shift from exchange value to sign value \\
\hline Science/Technology & Science/Technology \\
\hline Mechanical technology & Digital /Communicative technology \\
\hline Sciences & Humanities \\
\hline Euro-American centrism & Globalism \\
\hline Phallocentrism & Feminism/Genderism \\
\hline Orientalism, colonialism & Multiculturalism, globalism \\
\hline
\end{tabular}

Source: Venkatesh, et., al., (1993)

Indeed postmodernism is a reaction from modernism, if modernism relies on human ratios and believes in truth that is absolute, and has optimism about the problems of human life, then postmodernism does not attach importance to systematic and logical thinking. In addition, postmodernists also state that nothing is absolute, everything is relative, temporary, subjective and personal. Middleton \& Walsh described modernity as an attempt to erect a tower of Babel that wanted to unite mankind (Gen, 2011: 4). Postmodern has an attitude of distrust or declares the end of several important things, such as: (1) Distrust of the concept of the objective world; (2) Distrust of metanaration; and (3) Distrust of Science.

At least we see in the field of culture proposed by Frederic Jameson, that postmodernism is not a criticism of only one field, but all fields that are included in culture. The hallmark of thinking in the postmodernism era is plurality of valued thinking, everyone can speak freely according to his thoughts. Postmodernism rejects the arrogance of every theory, because every theory has its own ideas and it is useful.

\section{Ethics}

Etymologically the word ethics comes from the Greek which is in the singular form ethos and in the plural form ta etha. "Ethos" which means attitude, way of thinking, character of decency or custom. This word is identical with the moral words that come from the Latin word "mos" which is in the form of the touch Mores which also means custom or way of life. This word mores has a synonym; mos, moris, manner mores or manners, morals. In the Indonesian language the word moral means morals or morals which contain the meaning of 
mental order or conscience of conscience which is a guide for inner behavior in life. Ethics and Moral have the same meaning, but deep daily use there is little difference. Moral is usually used for the act being assessed / assessed (in other words the act is seen from within the person himself), meaning that moral here is the subject, while ethics is used for the study of the system of values that exist in certain groups or communities (an activity or assessment results).

\section{Business Ethics}

Business Ethics, how a business person (businessman) must act in his business field to support human life, both for himself and for other humans (Erni, 2011). Philosophers use two standards in discussing ethics, namely general ethics and special ethics. Specific ethics question how one must act in a particular field or problem and that field needs to be arranged in order to be able to support the achievement of human life as a human being (Erni, 2011). As with other fields of ethics, the conduct of business ethics must refer to morals which contain values and norms and principles that hold the businessman in regulating his behavior so that it can prosper the community and humanize humans through its business activities.

Business Ethics is a way to conduct business activities, which includes all aspects relating to individuals, companies and also society. Business Ethics in a company can shape the values, norms and behavior of employees and leaders in building fair and healthy relationships with customers / business partners, shareholders, the community. The cases studied generally show that the Company believes that good business principles are ethical business, namely a business with superior and sustainable performance that is carried out by complying with ethical principles in line with applicable laws and regulations.

Business Ethics can be a standard and guide for all employees including management and make it a guideline for carrying out daily work with moral virtues, honesty, transparency and professional attitude. Three basic approaches in formulating business ethics behavior, namely: (1) Utilitarian Approach: every action must be based on the consequences. Therefore, in acting a person should follow ways that can provide maximum benefits to the community, in a way that is not harmful and at the lowest possible cost; (2) Individual Rights Approach: everyone in their actions and behavior has basic rights that must be respected. However, these actions or behaviors must be avoided if they are expected to cause a conflict with the rights of others; and (3) Justice Approach: decision makers have the same position, and act fairly in providing services to customers individually or in groups.

Business views which rely solely on human exploitation are considered to be contrary to ethical values. Business and economic activities are essentially aimed at the welfare of humanity, not on the contrary exploiting and making people far from feeling prosperous and prosperous. Competition in business cannot be used as an excuse for not applying ethical values in one's business.

In order to achieve its goals, business ventures cannot escape from the atmosphere of competition. Indeed, competition in the business world is only a trigger for achievement, efficiency and productivity aimed at improving and improving the quality of the community (community). Every business goal that will be set by the company should duly refer to the positive values that are shared expectations. A company is born and exists for the customer and in fact the position of the customer (the general public) is part of the company itself.

In order to realize this interdependence, ethics is needed as an adhesive of different interests, but has the same goal, namely human welfare as the accumulation of the welfare of individuals. As long as business activities are aimed at creating mutual prosperity and not for business people only, the implementation of business ethics that is considered wise one of them is philosophy. Philosophical business ethics in many ways can unite two different 
values that are buyers and sellers, superiors and employers, and consumers with producers in realizing human interests as a whole.

Kattsoff's (1986) research, produced a critical and fundamental thinking about moral teachings and views, where ethics is closely related to various issues of moral and immoral values, good and bad and related to the basic principles of justification in relation to human behavior Principles justification in business must be studied scientifically by referring to ethical theories in philosophy whose truth has been tested. In other words, ethics is a separate science which is supported by theories namely ethical theory. As a science, the position of ethics focuses on efforts to seek information and truth as deep as possible, so that ethics carries out scientific tasks that is looking for indicators of the good and bad of human behavior.

2. Code of Ethics

Violations of the professional code of ethics are deviations / deviations from the norms set and accepted by a group of professions, which direct or instruct their members how they should do and at the same time guarantee the quality of the profession in the eyes of the public. The code of ethics for a profession is an oath of office which is also pronounced by State officials. Codes of ethics and oaths are promises that must be upheld (Erni, 2011). That is, there is no tolerance for anyone who violates it. True, strict sanctions are needed for violators of oaths and professional codes of ethics. In fact, if it fulfills the element of criminal or civil action, the violators of the oath and code of ethics should be brought to justice. We must indeed have the courage to be more assertive towards the misuse of the profession in any field. We also must not be discriminatory and selective in upholding the law in Indonesia. The code of ethics and oath of office must be upheld seriously. Any profession actually has no immunity in the field of law. Misuse of the profession by sheltering behind a professional code of ethics must be eradicated. We must put an end to the fraudulent and manipulative practices of some of the community's elite. This is important to do, if Indonesia wants become a dignified nation and nation. In other words, violations of the professional code of ethics are violations committed by members and / or a group of professions that do not reflect or give instructions to members how they should do and at the same time guarantee the quality of the profession in the eyes of the community.

The code of ethics is prepared by professional organizations so that each profession has its own code of ethics. For example, a code of ethics for doctors, teachers, librarians, lawyers, violations of the ethical code is not tried by the court because violating the code of ethics does not always mean breaking the law.

3. Ethics of Using the Internet

The internet is the acronym for Interconnection-networking which has the understanding of all interconnected computer networks that use the standard global Transmission Control / Internet Protocol Suite (TCP / IP) system. In other words Netiquette is a guideline for interacting with fellow Internet users. The Netiquette standard itself is set by a body called The Internet Engineering Task Force (IETF), an international community which is a collection of researchers, network designers and operators who play a role in the operation of the internet. The internet is also a network that connects computers throughout the world without being limited by the number of units into one network that can access each other. With the internet, one computer can communicate directly with other computers in various parts of the world. The reasons why this era had a significant impact on various aspects of life, namely: Information on the internet can be accessed 24 hours a day; Low cost and free materials; Easy access to information and conducting transactions; Ease of building relationships with customers; Internet users have penetrated in various directions. 
a. The Importance of Ethics in the Virtual World

The presence of the internet in human life has shaped its own community. Correspondence that used to be done traditionally (post carrier or post office) can now be done simply by sitting and typing the letter in front of a computer.

Some reasons for the importance of ethics in cyberspace are as follows: (1) That internet users come from various countries that may have different cultures, languages and customs; (2) Internet users are people who live in the anonymouse world, which do not require a statement of real identity in interacting; (3) Various kinds of facilities provided on the internet allow one to act ethically as for example there are also residents who like to fad by doing things that should not be done; (4) It must be noted that internet users will always increase at any time and allow the entry of new "residents" in the virtual world.

b. Some Examples of Ethics in Internet

With the increasing number of internet users, it is automatically prone to occur friction between fellow internet users. For this reason, we need an ethics that serves as our guide in using the internet, and the following are examples of some internet ethics:

1. Be careful of the information we receive. Through the internet we can get as much information. Whether it's spam, hoax news and others. Use references to trusted news sources or look for other sources of information, if you want to find out whether the information received is true or not.

2. Avoid personal attacks, often in forums in cyberspace there are debates between fellow internet users. Sometimes it can heat up so that the vocabulary delivered is not polite. Even so do not ever use the weaknesses of the opponent debate, as a weapon to win the debate, because it will show that how shallow knowledge.

3. Sending files or Attachments in E-mail. Not carelessly attaching files via e-mail. Note the file size that we will attach. Not until it's too big. Because it affects the recipient of our email. The solution is try before attaching, the file that we send will be compressed first so that the file size can be minimized.

\section{Violation of Ethics in the Maya world}

Like ethics in social life, the sanctions for violations are social sanctions. Social sanctions can be in the form of reprimands or even excluded from social life.

Likewise, internet ethical violations. Sanctions that will be received if they violate the ethics or norms that apply are excluded from the life of internet communication. Like if we have an account in a forum, when we violate publishing SARA-smelling articles, pornography, or mocking other people or groups, then our account can be deactivated or banned from the forum.

\section{War without form (proxy war)}

The term proxy war was originally interpreted as a puppet war or guardian war, but not asymmetrically or non-militarily, that it was still carried out in the context of open (symmetrical) military warfare as was the case in Ukraine, Syria, etc. But this war began to be packaged in variants, military wars such as hybrid war, city war, guerrilla, etc. Proxy war is a formless war between two or more countries that avoids direct warfare, rather than supporting fighters who serve their interests. When one country fights, another supports the enemy. Various sources began to use the term proxy war to describe the conflict in Yemen, as if on cue, after Saudi Arabia launched a bombing campaign against Houthi targets in Yemen on March 25, 2015 (Clark 2010: 27). 
Furthermore Parry (2015: 2-18) explains that proxy war occurs when the power of the opponent has used a third party as his successor to attack directly. While power is sometimes used by the government as a proxy, such as non-state actors, violence, mercenaries, and other third parties, with the hope that this group can attack opponents without causing full-scale war. But proxy war is impossible to do purely, because the group can fight for their own interests, and have deviated from their main duties. Usually the proxy war functions optimally during the cold war, because it becomes a necessity in carrying out armed conflict between two or more parties who fight continuously.

In other words, proxy war no longer uses weapons, but uses thought. Thus, proxy war is more dangerous than war which uses the main weapon system (defense equipment), because through thinking with brainwashing that will distort understanding of the state ideology.

The nature and characteristics of proxy war have shifted along with technological developments. The possibility of a conventional war between two countries today is getting smaller. However, the demands of group interests have created new types of wars. Among them, asymmetrical warfare, hybrid warfare, and proxy warfare. Asymmetric warfare is a war between belligerents or warring parties whose military strength is very different. Hybrid or combination warfare is a war that combines conventional warfare techniques, asymmetrical warfare, and information warfare to gain victory over the opponent.

When conditions are strong, conventional wars are fought to defeat the opposing party. However, when the situation is less favorable, other methods are used to weaken the enemy. Proxy war is a confrontation between two major powers by using substitute players to avoid direct confrontation with the reason to reduce the risk of direct conflict that is at risk of fatal destruction. Usually, the third party acting as a substitute is a small country, but sometimes it can also be non-state actors which can be NGOs, CSOs, community groups, or individuals. Through this proxy war, it cannot be clearly identified who is friend and who is the opponent because the enemy controls non-state actors remotely. Proxy war has taken place in Indonesia in various forms, such as separatist movements and others in the life of the nation and state.

Proxy war (war without form), is part of the asymmetric warfare mode, so it is of a different type from conventional warfare. Asymmetric warfare is irregular and is not limited by the size of the tempura or the extent of the battle area. Proxy war utilizes external disputes or third parties to attack the interests or ownership of the opponent's territorial. Proxy war, it is not clear who is friend or foe, because the enemy is controlling from afar. Proxy war is an extension of a country's efforts to get its strategic interests. But in order to avoid direct involvement by waging an expensive and bloody war.

The proxy war in Indonesia is actually a conspiracy to explore oil and gas in the Timor Sea. Oil in the Timor Sea is in the midline between Timor Leste and Australia and has attracted the attention of the Australian government since the 1960s. Proxy war has taken place in various forms. In addition to the separatist movement, these efforts were carried out through a number of moves. Among the mass demonstrations, the system adverse regulations, or clashes between groups. Demonstrations that carry unreasonable and coercive demands, for example, should be suspected as indications of proxy war in Indonesia. The mass media has an extraordinary ability to influence and shape public opinion which can be used as a proxy war vehicle in Indonesia.

All of this we must look at, we anticipate that Indonesian people will not be trapped in this arena. The commitment of the national mass media, including the authors of the book, is one solution to educate and educate all the children of the nation. In the current era of 
democracy, Indonesia is no longer a mass media that is based and oriented to the government, which is willing and able to disseminate all information that comes from the government or the country.

Indonesia is a country with abundant natural resources. It is not wrong if Indonesia's natural wealth becomes the target of foreign countries. We must be vigilant with the natural wealth we have because it is a struggle for foreign countries. "The government does not have mass media that is used as a funnel as in the past, so practically there is no media that bridges information from the government to the public".

The future war is a war on food, water and energy, - termed the economic war and its location in Indonesia in the future, energy can be replaced with biological energy. Biodiversity exists in countries on the equator, especially in Indonesia. "Therefore, Indonesia has the potential to become a food barn, a barn of water, as well as a barn for biological energy. The proxy war currently has an energy background and is now increasingly apparent with the shift in world conflict.

Currently the remaining world energy reserves are 45 years remaining and will be exhausted if we all do not try to find a replacement, because energy consumption in 2025 increased 45 percent, while the increase in energy in 2007-2009 also triggered an increase in world food prices reaching 75 percent.

On the other hand, there are only countries crossed by the equator that are able to grow crops throughout the year. These countries are Latin America, Central Africa, and Indonesia itself. Meanwhile, the world population will reach 12.3 billion, it will occur in 2043 , the number is three times the capacity of the earth. In this world there are only 2.5 billion people who live on the equator, while for the rest of the population there are some 9.8 billion that are outside the equator. This condition triggered a war to take over the energy of countries that are on the equator, one of which is Indonesia.

At present what is happening is that today's war against the background of energy will experience a shift to a war on food, water and energy. Where initially occurred in the Middle East region, it will automatically shift towards Indonesia, Central Africa, and Latin America. The world will run out of energy.

Many ways are carried out by foreign countries to control Indonesia's natural wealth. We have felt this, namely the existence of a proxy war and we have begun to be aware, because it has infiltrated the joints of the life of the nation and state, the way to control the media in Indonesia, creating TNI-Polri sheepfighting, social engineering, cultural change, party splitting and drug smuggling has done long ago.

\section{Good corporate governance}

Corporate Governance is "referring to a group of people getting together as one unit with the task and responsibility to direct, control and rule with authority. On a collective effort this body is empowered to regulate, determine, restrain, urban exercise the authority given it "(Solomon, 2007: 13). The concept of comprehensive corporate governance began to develop since the New York Stock Exchange crash 'On October 19, 1987, where many multinational companies listed on the New York Stock Exchange, suffered substantial financial losses (Monks and Minow, 2003: 19).

The World Bank defines GCG "is a collection of laws, regulations and rules that must be met that can encourage the performance of company resources to work efficiently, generating long-term sustainable economic value for shareholders and the surrounding community as a whole". Forum for Corporate Governance in Indonesia (FCGI). FCGI defines corporate governance as: "... a set of rules governing the relationship between 
holders, management (managers) of the company, creditors, government, employees, and other internal and external stakeholders relating to their rights and obligations or with In other words, a system that controls a company. The purpose of corporate governance is to create added value for all interested parties (stakeholders).

The various definitions of Corporate Governance conveyed above, have a common meaning that emphasizes how to regulate the relationship between all parties concerned with the company that is realized in a corporate control system, in other words, basically the basic principles of GCG compiled mainly by the OECD consist of five aspects namely: Transparency, can be interpreted as information disclosure, both in the decision making process and in disclosing material and relevant information about the company; Accountability, is the clarity of functions, structure, systems and accountability of company organs so that company management is carried out effectively; Responsibility, corporate responsibility is conformity (compliance) in the management of the company with sound corporate principles and applicable laws and regulations; Independence, or independence is a condition where the company is managed professionally without any conflict of interest that is not in accordance with applicable laws and regulations and sound corporate principles; Fairness (equality and fairness), namely fair and equal treatment in fulfilling stakeholder rights that arise based on agreements and applicable laws and regulations.

Based on various GCG definitions conveyed above, it can be seen that there are five main objectives of Good Corporate Governance, namely: (1) protecting the rights and interests of shareholders, (2) protecting the rights and interests of members of the stakeholders non-shareholders, (3) increasing the value of the company and its shareholders, (4) increasing the efficiency and effectiveness of the work of the Board of Directors and Board of Directors and company management, and (5) improving the quality of the Board of Directors' relationship with the company's senior management.

The five main objectives of the GCG show signs of how important the relationship between the parties that have interests with the company so that good corporate governance is needed. In Indonesia, the objectives and benefits of GCG can be known from the Decree of the Minister of State Owned Enterprises through Decree No. Decree 23 / M-PM. PBUMN / 2000, Article 6, Implementation of GCG in the context of protecting the interests of PERSERO aims to: (1) develop and increase company value; (2) management of resources and risks more efficiently and effectively; (3) improvement of discipline and responsibility of PESERO's organs in order to safeguard the interests of the company including shareholders, creditors, employees, and the environment in which PESERO is located, reciprocally in accordance with their respective duties, authorities and responsibilities; (4) increasing PESERO's contribution to the national economy; (5) improving the investment climate; and (6) supports the privatization program.

According to KNKG, companies that have responded by implementing better corporate governance policies and practices do not place GCG implementation as an end, but the company realizes that it is very important to achieve: (1) improving company performance through better decision making procedures, more efficient operations and better service delivery; (2) Access to low-cost financing for new technologies, management expertise, markets, and other sources of financing, which will bind the firm's value; (3) Satisfied investor community because companies provide better dividends and corporate value on the results of improved financial performance; (4) The long-term survival of the company and the creation of value while taking into account the interests of all stakeholders; (5) Sources of Government revenue through BUMN privatization, as well as payment of dividends and taxes by SOEs. 
In addition to the benefits and objectives as explained above, the application of GCG at least four ideal situations are to be achieved, namely: (1) Existence of fair business: efficient market, efficient regulation, and efficient contract; (2) Information regarding the (fair) prices and specifications of goods and services being exchanged is available to all parties; (3) Each party is able and is willing to comply with the rules and regulations, terms and conditions contract; (3) Judicial processes exist and are able to implement the rules and to execute punishment to the non-compliant of the contract.

In addition, good corporate governance is recognized as helping to "frustrate" the company from unfavorable conditions, in many cases good corporate governance has been proven to improve company performance by up to $30 \%$ above the normal rate of return, therefore, Good Corporate Governance provides benefits in improving communication, minimizing the potential for collisions, focusing on key strategies, increasing productivity and efficiency, sustainability of benefits, promoting corporate image, increasing customer satisfaction, and gain investor confidence.

When the Limited Liability Company is regulated in the Commercial Law Code (KUHD) many argue that the provisions have been left behind or are not accommodating to accommodate the needs of the community in the field of corporate law, so that the discourse arises to replace and make a Draft Law on Limited Liability Companies.

In 1995, Law No. 1 of 1995 concerning Limited Liability Companies was successfully issued. The issuance of this UUPT is awaited with hope, because there will be a strong legal basis to run the company and provide maximum legal protection and is considered a step forward compared to the KUHD, because many things have been regulated by the UUPT that were not previously regulated in the KUHD. However, in the course of Act No. 1 of 1995 received sharp criticism from various circles, it turns out that there is a lot of uncertainty about what is stipulated in the Law on Limited Liability Companies, such as how to protect minority shareholders, how is the responsibility of members of the board of commissioners, how is the responsibility of directors in run company management, then how is the legal relationship between shareholders and agents who carry out company management and so on.

The presence of the Audit Committee is evidence that the Company Law and the Capital Market Law have lagged behind many business developments. This lag can be explained from the basis of the arrangements and practices of the audit committee so far in Indonesia. Audit Committee Arrangements while referring to the provisions in KepMen BUMN No. Kep-103/2002 and GCG guidelines.

In this UUPT condition and not supported by good business practices, where business practices in Indonesia get the lowest scores in several Asia Pacific countries, competitiveness is also very low, even decreasing, as a result of unfair business competition, collusion occurs between entrepreneurs and the authorities, the increasingly widespread acts of KKN, both in business and government activities. On the one hand, the paradigm of the Good Corporate Gavernance principle increasingly exists throughout the world, and the results of evaluators from various international institutions in Indonesia are among the countries with the lowest GCG implementation.

Recognizing this fact, it is necessary to have efforts to improve the performance of companies in Indonesia, it is necessary to restructure good corporate governance in Indonesia if you want to survive and be able to compete in the global market. The rearrangement will begin with improvements to regulations governing business activities, such as the Company Law, Capital Market Law, Banking Law, Anti-Monopoly Law, and so on. The rearrangement 
referred to is the regulation in the business sector adjusted to the paradigm of GCG principles.

As explained above, the paradigm of GCG principles developed by the OECD consists of five principles that are considered ideal that must be included in every application of corporate governance. If the five principles are elaborated and analyzed into Indonesian company law, the following matters can be known: (1) Protection of Shareholder Rights, Company Law. In Indonesia, the Indonesian Company Law recognizes some of these principles, however, the arrangements are relatively summarized, where more principles have not been applied or not, for example the principle of listing shares or proof of ownership or the principle of obtaining relevant information about the company in a timely manner, except for public companies, and even that is still not fully implemented. Especially private companies of medium and small scale, most of which are not recorded, even very rarely do the accountability of directors at the end of each company financial year or conducted audits, and so on. (2) Equality of Treatment of All Shareholders, Corporate Law in Indonesia does not holistically regulate this principle, as stipulated in Article 46 paragraph (2) of the Company Law, it is stated that "every share in the same qualification gives equal rights to holders", but the protection of each shareholder is in fact not equel. If explored further, this principle is one aspect that needs to be prioritized. in the application and or regulation of corporate governance in Indonesia. In practice the problem of protecting minority shareholders is still full of controversy, and often is merely a normative discourse.

To anticipate the company's internal control problems, there are many cases about financial engineering, how to hide losses or beautify the performance of management and financial reports through window dressing or finacial engineering (Monks and Minow, 2003: 69). Generally in a conducive business situation, irregularities within the company look very vague, but when difficulties begin to reveal the company's losses and bankruptcy. Since the publication of the 'Cadbury Code on Corporate Governance, including the International Corporate Governance Network (ICGN) which has encouraged the Organization for Economic Cooperation and Development'. ICGN is very interested in implementing GCG because their members consist of pension and insurance institutions that manage customer funds for long-term investment (Solomon, 2007: 68).

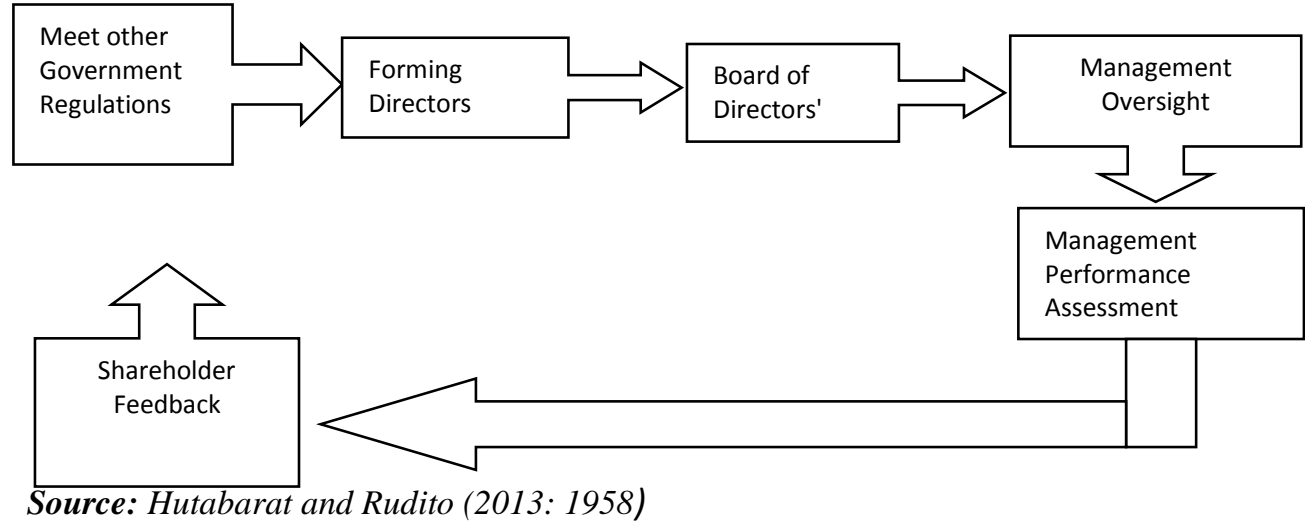

Figure 1. Circle of GCG Mechanism

Corporate governance consists of a set of interrelated mechanisms which consist of institutional shareholders, board of directors and commissioners, managers who are paid based on performance, the capital market as a controlling shareholder, ownership structure, financial structure, related investors and product competition (Kelton and Yang 2008). The management mechanism of Good Corporate Governance ensures that management actions 
will always be directed at increasing company value, as well as a form of attention to the stockholders, employees, creditors and the surrounding community (Figure 1).

Feedback concerning: the results of the assessment of the system, the results of the analysis and study, the results of the implementation of the concept, and the results of the evaluation. The principle that must be obeyed on the CG mechanism is independence, integrity and transparency which must be carried out effectively and continuously (McKendall, Sanchez, and Sicilian, 1999: 216).

Legal framework as Law of PT. Number 1 year 95; Capital Market Law Number 8 Year 95; SOE Law Number 19 of 2003; Government Regulation Kep.Men BUMN Number 103 Year 95; Bapepam Circular Letter Number 03 Concerning Capital Market Year 2000; and Circular Letter No. 5 / BEJ / 09/2001. The board is a group of individuals chosen with the primary responsibility being the actions of the owner's interests by formally monitoring and controlling the top corporate executives. The Board of Commissioners forms the Board of Directors (management). The function of the board of directors is a management control function that systematically sets performance standards with planning objectives to design feedback information for shareholders, comparing work performance with predetermined standards, and whether irregularities have been taken to ensure that company resources are used effectively in order to achieve company goals.

In the Free Market era, business activities began to be demanded to develop, implement new systems and paradigms in business management namely the Principles of Good Corporate Governance (abbreviated as GCG). The main driver of the growing need for good corporate governance practices as a result of bankruptcy of well-known companies, such as Polly Peck, BCCL, WorldCom in the US, HIH and One-tel in Australia.1 The same event occurred in Indonesia, many companies went bankrupt indicated as a result of not applying the GCG Principles, in addition to the many practices of Corruption, Collusion and Nepotism (CCN).

Based on the PricewaterhouseCoopers study published in the 2002 Report on Institutional Investor Survey, Indonesia ranked lowest with China and India with a value of 1.96 for transparency and openness. In 2003, CLSA reported the results of a study on the implementation of GCG in Asia which showed that Indonesia ranked lowest or worst in Asia with a score of 1.5 for law enforcement issues, 2.5 for institutional mechanisms and corporate governance culture, with a total score of 3.2. Even though Indonesia's score in 2004 was better compared to 2003, however, Indonesia still ranks lowest among Asian countries3, as shown in the table below.

Based on the data in the table above shows that the laws and regulations in the country of Indonesia which regulate business activities are weak and are coupled with very weak law enforcement compared to other Asian countries. Based on the description above, the problem discussed in this paper is how the implementation of GCG principles in companies in Indonesia, whether regulatory regulation is required in applying the GCG principles.

As a concept, good corporate governance (GCG) apparently does not have a single definition. The Cadburry Committee, for example, in 1992 - through what is known as the Cadburry Report - issued its own definition of GCG. According to the Cadburry Committee, GCG is a principle that directs and controls the company in order to achieve a balance between the strength and authority of the company in providing accountability to shareholders in particular, and stakeholders in general. Of course this is intended to regulate the authority of Directors, managers, shareholders, and other parties related to the development of the company in a particular environment. 
Table 4. Corporate Governance in Asia Continuing Under Performance

\begin{tabular}{|c|c|c|c|c|c|c|c|}
\hline \multicolumn{8}{|c|}{ Markets ranked by corporate governance } \\
\hline & $\begin{array}{l}\text { Rules\& } \\
\text { regulation } \\
\text { (15\%) }\end{array}$ & $\begin{array}{c}\text { Enforce } \\
\text { ment } \\
(25)\end{array}$ & $\begin{array}{l}\text { Political\& } \\
\text { Regulatory } \\
(20 \%)\end{array}$ & $\begin{array}{l}\text { IGAAP } \\
(20 \%)\end{array}$ & $\begin{array}{c}\text { CG } \\
\text { Culture) } \\
(20 \%)\end{array}$ & $\begin{array}{l}\text { Country } \\
\text { Score } \\
(2004)\end{array}$ & $\begin{array}{l}\text { Country } \\
\text { Score } \\
(2003)\end{array}$ \\
\hline Singapore & 7,9 & 6,5 & 8,1 & 9,5 & 5,8 & 7,5 & 7,7 \\
\hline Hong Kong & 6,6 & 5,8 & 7,5 & 9,0 & 4,6 & 6,7 & 7,3 \\
\hline India & 6,6 & 5,8 & 6,3 & 7,5 & 5,0 & 6,2 & 6,6 \\
\hline Malaysia & 7,1 & 5,0 & 5,0 & 9,0 & 4,6 & 6,0 & 5,5 \\
\hline Korea & 6,1 & 5,0 & 5,0 & 8,0 & 5,0 & 5,8 & 5,5 \\
\hline Taiwan & 6,3 & 4,6 & 6,3 & 7,0 & 3,5 & 5,5 & 5,8 \\
\hline Thailand & 6,1 & 3,8 & 5,0 & 8,5 & 3.5 & 5,3 & 4,6 \\
\hline Philippine & 5,8 & 3,1 & 5,0 & 8,5 & 3,1 & 5,0 & 3,7 \\
\hline China & 5,3 & 4,2 & 5,0 & 7,5 & 2,3 & 4,8 & 4,3 \\
\hline Indonesia & 5,3 & 2,7 & 3,8 & 6,0 & 2,7 & 4,0 & 3,2 \\
\hline
\end{tabular}

Source: CLSA Asia-pacific Market, Asian Corporate Governance Assocition 2015.

A number of countries also have their own definitions of GCG. Some countries define it with a somewhat similar understanding even though there are slight differences in terms. Developed countries group (OECD), for example defines GCG as ways for the management of the company to be responsible to its shareholders. Decision makers in the company must be accountable, and the decision is able to provide added value for other shareholders. Therefore, the main focus here is related to the decision making process of the company which contains the values of transparency, responsibility, accountability, and of course fairness.

Meanwhile, ADB (Asian Development Bank) explained that GCG contains four main values, namely: Accountability, Transparency, Predictability and Participation. Another understanding came from the Finance Committee on Corporate Governance Malaysia. According to the institution, GCG is a process and structure used to direct and manage business and company affairs in the direction of increasing business growth and corporate accountability. The final goal is to increase the value of shares in the long term but still pay attention to the various interests of other stakeholders.

The role of postmodernism in ethics, proxy war and its ilmplication of good corporate gaovernance

If the basis of modernism shows that there is an objective world, then postmodernism adheres to nonrealist and constructivist practices. Nonrealists deny that we can see reality objectively. In other words, the postmodernist view, that God and all concepts related to values, morality, spirituality and supernatural / immaterial reality are mere concepts. They are just 'linguistic symbols' without an objective reference. These postmodernists embrace a pluralistic concept of knowledge, a rejection of a single objective world or something that is used as a basis for evaluating the right or wrong of a concept or knowledge.

According to postmodernism, metanaration is a system that validates myths. Where in fact metanaration has power that is not derived from argumentation or proof but rather the main means by which the group finds its validity. Modernism collapsed because the main narrative that sheltered it had lost its power. The concept of postmodernism does not believe in a central myth that makes everything absolute. Postmodern era is a period where everything is not validated, which always attacks the view that considers itself universal. 
Even though postmodern people break away from metanaration, they still maintain local narratives.

Modern science has the desire to eliminate 'scientific' knowledge such as beliefs, myths and primitive stories that are used to explain the truth of the world. But according to postmodernists, science will not be able to dispel myths from the area of knowledge. Instead, science must return to the narrative to get its endorsement. According to Lyotard, the postmodern situation produces findings because inventions are always born from differences of opinion, not from consensus. Postmodernists value diversity more than diversity, respect local and particular things more than universal, so that it means the end of the concept of 'world,' 'metanaration' and 'science.' These latest discoveries have introduced a revolution of perspective scientists like, new ways of looking at the universe and new ways of scientific research.

Postmodernism, refers to the indications of a proxy war, including: separatist movements, mass demonstrations, adverse regulatory systems, drug trafficking, provocative media coverage, the spread of pornography and free sex, student brawls, and clashes between groups (Gatot, 2017). Furthermore, according to political observers and global strategists of superpower in this world a real fact or is it just an illusion and paranoid. However, the results of academic discussions conducted at the University of Indonesia in Jakarta, Malang, Brawijaya University, Bandung Institute of Technology, and the Jakarta National Resilience Institute, concluded that several forms of conditions if Indonesia had become a proxy war material: (1) Making Indonesia a market for foreign products; (2) Inhibiting the development of Indonesian human resources and technology in order to lose global competitiveness; (3) Recruiting Indonesian young generation with indoctrination accompanied by educational facilities and materials, so that they want to become agents of foreign countries, if they become the leaders of the Indonesian nation in the future, they will be able to be controlled by the government of the foreign country; (4) Foreign countries will make large-scale investments in strategic industries, in order to dominate the strategic industrial sectors in Indonesia (oil and gas, mining, electricity, communications, satellites, Republic of Indonesia's Military Weapons, Bluechip Stocks, etc.); (5) Foreign parties try to create regional and world free market pacts, so that Indonesian local products become depressed and destroyed. Penetrate, infiltrate, bribe, and collusion with Indonesian legislative members, so that its strategic legal products will benefit foreign parties; (6) Foreigners make large-scale investments in Indonesia; (7) Creating terrorist groups in Indonesia, so that under the pretext of combating world terrorism, foreign parties can freely intimidate and intervene in Indonesia.

The pretext to destroy world terrorism; (8) Buy and control the mass media, both print and electronic, to form public opinion that benefits foreign parties. Mastering high-tech communications technology industries, such as communication satellites and spy satellites, in order to be able to tap and monitor all the conversations of key Indonesian officials, as well as the locations of Indonesian military forces, and the wealth of Indonesian mines; (9) (10) Dividing and destroying Indonesian young generation with drugs, promiscuity, pornography and free sex, consumptive culture, and lazy laziness.

Postmodenisem, refers to how the structure of business entities is modified in such a way as to bridge and bring together the interests of various groups of different origin and motives. However, at the level of implementation, what is needed is not merely improvement of regulations, improvement of infrastructure and independent commissioners or audit committees. It is important to pay attention to the understanding as well as the firmness of the 
commitment of all parties involved in its implementation, to truly practice Good Corporate Governance.

Unhealthy corporate governance can lead to the temptation of misuse of Board positions and management of companies that are weak in business ethics and morals, so it can also harm the members of the stakeholders, especially shareholders, creditors, company suppliers and employees.

The implementation of CG can be explained through the essence of CG itself which is also related to Agency Theory (Jensen and Meckling, 1976). In a modern economy, corporate management and management are largely separated from company ownership. This is in line with the Agency Theory which emphasizes the importance of company owners (shareholders) handing over the management of the company to professionals called agents who are more understanding in running their daily business.

The purpose of separating management from company ownership, is so that the owner of the company gets the maximum profit possible with the most cost efficient as possible by the company being managed by professional staff. They, the professionals, work for the benefit of the company and have the discretion in carrying out the management of the company. So in this case the professionals act as agents of the shareholders. The greater the company managed to make a profit, the greater the benefits that are adapted by agents. While company owners (shareholders) only have the task of supervising and monitoring the running of companies managed by management and developing an incentive system for management managers to ensure that they work in the interests of the company (Jensen and Meckling, 1976). But on the other hand, separation like this has its negative side. The existence of the flexibility of the company's management to maximize the profit of the company can lead to the process of maximizing the interests of its own management with the costs and costs that must be borne by the company owner. Furthermore, this separation can also be borne by the company owner. Furthermore this separation can also lead to a lack of transparency in the use of funds in the company as well as the right balance between the interests that exist, for example between shareholders and managers company management and between controlling shareholders and minority shareholders.

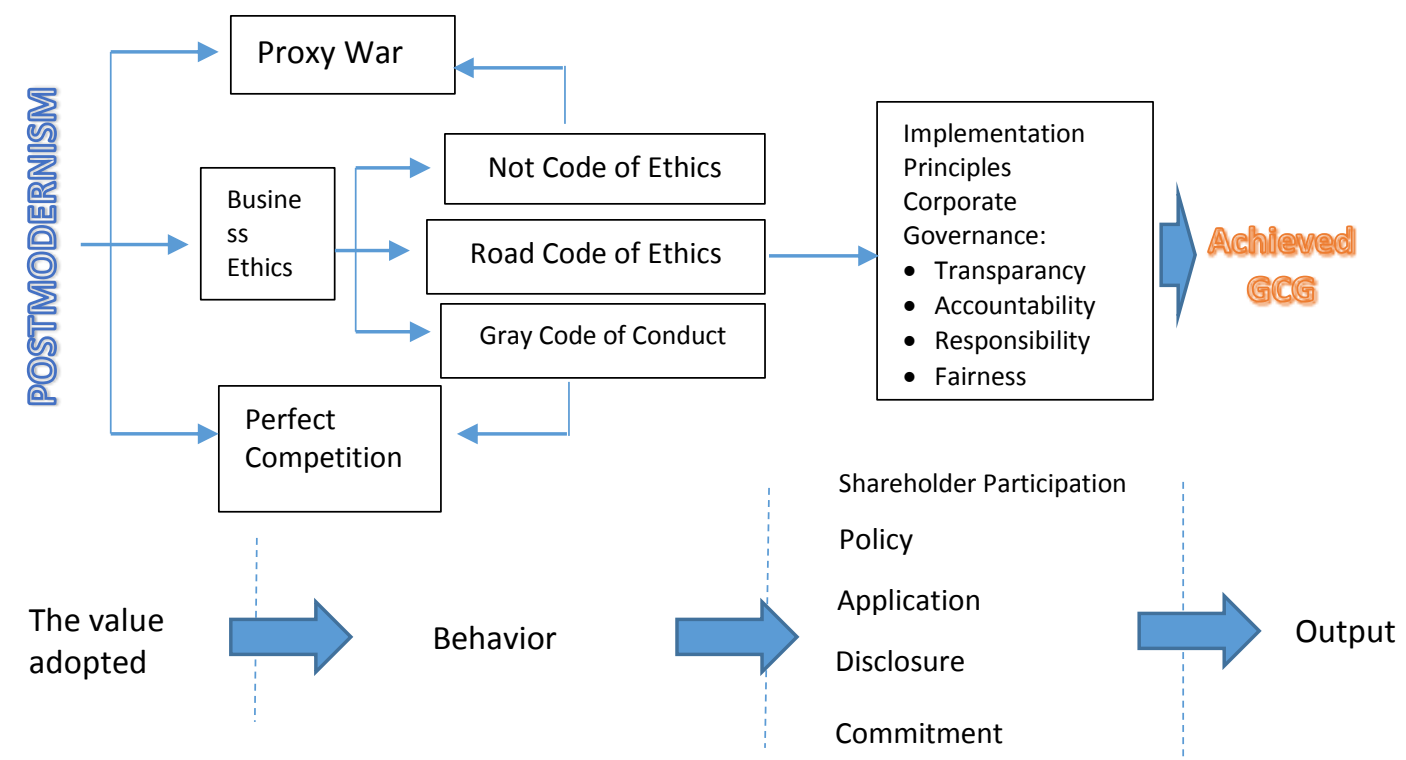

Figure 2. The Postmodernism paradigm, Proxy War, Business Ethics and its implications for GCG 


\section{The solution}

Postmodernism's view, which ignores ethics and emphasizes aesthetics, will create a proxy war, because all concepts related to values, morality, spirituality and supernatural / immaterial reality are only seen as mere concepts. In other words, we must return to modernism by sticking to essential values, morality, spirituality and supernatural / immaterial reality, by returning to understand well we are holy (such as Muslims with the Qur'an and Al Hadiths, Christians with the Gospel, etc. ) as the main guideline in understanding values, responding to agreed codes of ethics, then behaving positively.

The threat of proxy war, in the context of the national interests of the Indonesian people, must continue to be closely watched and addressed seriously. In order to always fortify both individuals (employees), groups (teams) and organization (Nation or company), and stakeholders of the Unitary Republic of Indonesia (NKRI) from the influence and threat of the danger of proxy war by: Strengthening faith and piety to God Almighty , maintain teamwork solidity, and make ethics as a basis for thinking, acting and acting in the form of life both individuals, groups and organizations (countries or companies) in facing the dangers and threats of proxy war. Do not easily slip in a moment that will determine the fate of the organization, as we face today, large or subtle slander, hard or weak deception, visible or hidden provocateurs, all of which God willing, we can go through safely, if alone we remain vigilant and vigilant, upholding the establishment of ideals, as citizenship organizations (Indonesian citizens or employees).

The threat of proxy war in the context of corporate interests can be overcome by exploring the cultural values of companies that can adapt to business ethics through good governance, planning, organizing, implementing, and controlling by involving shareholders in formulating policies, then working on agreed policies, then reveals the results with full commitment to transparency, accountability, responsibility and fairness.

As Academics:

Academics as the backbone of the organization (nation and / or company), must be aware of the various challenges and threats of this organization, to then unite and work together to maintain the safety of the organization (both nation and state and company). A number of actions that can be taken by academics to counteract postmodern understanding as an effort to overcome proxy war include: Always identifying and recognizing problems, experts in their respective disciplines, conducting entrepreneurial-based movements, and organizing campus communities and pioneering character building programs.

In an effort to that end, in this case academics, must equip their students with knowledge, expertise, and skills in accordance with their fields. Broad insight, experience to shape character and nationalism, so that it can fight and destroy proxy war in Indonesia.

\section{CONCLUSION}

In conclusion on this paper, several conclusions can be formulated, as follows:

1. Postmodernism is an understanding that developed after the modern era with modernism. Postmodernism is not a single understanding or a theory, but rather an umbrella for various theories that are scattered and difficult to find a single common ground.

2. Ethics is a branch of philosophy of ethics looking for good and bad measures of human behavior. Ethics want to find which human actions are good. Ethics deals with all knowledge related to humans and society such as: anthropology, psychology, sociology, economics, political science and law. The difference lies in the must aspect (ought). The difference with moral theology, because it does not rely on religious principles, but only 
limited to the knowledge generated from its own human power. This moral word in Greek is the same as ethos which becomes ethics.

3. Proxy War, a war without form. Proxy war has taken place in various forms, in addition to separatist movements, these efforts have been carried out through a number of steps, including mass demonstrations, adverse regulatory systems, and clashes between groups.

4. Corporate Governance is a collection of laws, regulations and rules that must be fulfilled with the aim of encouraging the performance of company resources as an effort to work efficiently, producing long-term sustainable economic value for shareholders and the surrounding community as a whole. However Thus, there are still various challenges faced by Indonesia from various aspects, namely (1) Inequality Development, Development that has not been evenly distributed and the high level of poverty, (2) Energy and Food Security, high dependence on energy and food imports to meet the needs domestic, (3) Basic Infrastructure and Industry, weak competitiveness of infrastructure and manufacturing, dependence on imported material costs, (4) Access to Financial Services, access to financial services in Indonesia is still low compared to other countries, and (5) Human Resources, the number of educated workers and the productivity of Indonesian workers is still low compared to regional workers. In encouraging development in the future, the Government has launched the basic direction of Nawacita as the basis for the entire Development Initiative as outlined in the 20152019 National Medium-Term Development Plan with various qualitative and quantitative targets. GCG implementation will be difficult to achieve if postmodernism is rooted in each stakeholder's, because it is not only widening the gap of interests between principals in this society as the owner of capital (State, Region, or company) and Agent in this case the government as the manager of the State / Region / Company (agency theory), but there will be a war without form (proxy war), because all stakeholders (stakeholders) override ethics, and further emphasize aesthetics.

\section{REFERENCE}

Ahmed, A., 1992. Postmodernism and Islam: Predicament and promise. New York, NY: Routledge.

Al-Amri H.A. 2005, The Yemen in the 18th \& 19th Centuries: A Political and Intellectual History, Garnet \& Ithaca Press, Reading

Asian Corporate Governance Association. 2012. Corporate Governance Watch 2012: Market Rankings. September, ACGA. http://www.acga-asia.org/public/files/CG _Watch_2012_ACGA_Market_Rankings.pdf [diakses 11/01/2017]

Barney, Jay B., and Deleyn N. Clark. 2007. Resource-Based Theory: Creating and Sustaining Competitive Advantage. New York: Oxford University Press.

Best, S. and D. Kellner, 1991. Postmodern theory: Critical interrogations. New York, NY: Guilford.

Bidwell R. 1983, The Two Yemens, Prentice Hall, Upper Saddle River

Burrowes R. 2005, Historical Dictionary of Yemen, Scarecrow Press, Lanham x

Burrowes R. 2008, The Yemen Arab Republic: The Politics of Development, 1962-1986, Croom Helm, London

Cahoone, Lawrence (ed.), 2003, From Modernism to Postmodernism: An Anthology, 2nd Edition, London: Blackwell Publishing, Ltd.

Carapico S. 2009, Civil Society in Yemen: The Political Economy of Activism in Modern Arabia. Cambridge: Cambridge University Press. 
Chen, J.,2001. Ownership Structure as Corporate Governance Mechanism: Evidence from Chinese Listed Companies, Economics of Planning, 34: 53-71.

Clark V. 2010, Yemen: Dancing on the Heads of Snakes, Yale University Press, New Haven Coombes, Paul and Mark Watson, 2000. Three surveys on corporate governance. The McKinsey Quarterly, Number 4 special edition: Asia revalued, pp. 74-7.

Dezoort, F.T. dan S. Salterio, 2002, The Effects of Corporate Governance Experience and Financial Reporting and Audit Knowledge on Audit Committee Members' Judgments. Auditing: A Journal of Practice \& Theory, 21 (Fall): Forthcoming.

Dresch P. 1989, Tribes, Government and History in Yemen, Oxford University Press, Oxford

Dresch P.A., 2000, History of Modern Yemen, Cambridge University Press, Cambridge

Enders K. 2002, Yemen in the 1990s: From Unification to Economic Reform, International Monetary Fund Washington

Erni R. Ernawan, Rusdin, Taufani, dan Thoma Gozali, 2016. Optimalisasi Kinerja Perusahaan Berbasis Etika. Bandung: Alfabeta.

Erni R. Ernawan, 2011. Etika Bisnis. Bandung: Alfabeta

Erni R. Ernawan, 2010. Budaya Organisasi. Bandung: Alfabeta

Featherstone, M., 1991. Consumer culture and postmodernism. London: Sage Publications.

Firat, A.F. and A. Venkatesh, in press. The making of postmodern consumption. In: R.W. Belk and N. Dholakia (eds.), Consumption and marketing: Macro dimensions. Belmont, CA: Wadsworth.

Firat, A.F., 1990. The consumer in postmodernity. In: R.H. Holman and M.R. Solomon (eds.), Advances in Consumer Research, XVII. Provo, UT: Association for Consumer Research.

Firat, A.F., 1991. Postmodern Culture, Marketing and the Consumer. In: T.L. Childers et al. (eds.), Marketing theory and application, 237-242. Chicago, IL: American Marketing Association.

Firat, A.F., 1992. Fragmentations in the postmodern. In: J.F. Sherry, Jr. and B. Sternthal (eds.), Advances in Consumer Research, XIX, 203-206. Provo, UT: Association for Consumer Research.

Gerges F.A. 2015, Contentious politics in the Middle East: popular resistance and marginalised activism beyond the Arab uprisings, Palgrave Macmillan, London

Ghamari, Magdalena El. 2015. Jemen - the Proxy War. Securitologia No 2. https://www.researchgate.net/publication/305192244_Jemen_-_the_Proxy_War.

Habermas, Jürgen, 1987, The Philosophical Discourse of Modernity, Frederick Lawrence (trans.), Cambridge: Cambridge University Press.

Halme, M.. \& Huse, M., 1997. "The Influence of Corporate Governance, Industry and Country Factors on Environmental Reporting". Scandinavian journal of Management, 13 (2): 137-157.

Hart O., 1995. Corporate Governance: Some Theory and Implications, Economic Journal, n. 105.

Harvey, D., 1989. The condition of postmodernity. Cambridge, MA: Blackwell.

Heidegger, Martin, 1994. Basic Questions of Philosophy: Selected "Problems" of "Logic," Richard Rojcewicz and Andre Schuwer (trans.), Bloomington: Indiana University Press.

Holbrook, M.B., 1990. The role of lyricism in research on consumer emotions: Skylark, have you anything to say to me?. In: M.E. Goldberg, G. Gorn and R.W. Pollay (eds.), Advances in Consumer Research, XVIII, 1-18. Provo, UT: Association for Consumer Research. 
Ingrams H.W. 2009, The Yemen: Imams, Rulers, \& Revolutions, Praeger, Santa Barbara

Jameson, F., 1991. Postmodernism, or the cultural logic of late capitalism. Durham, NC: Duke University Press.

Jensen, Michael C. and W. Meckling, 1976. The Theory of firm: Managing Behavior, Agency Cost and Ownership Structure, Journal of Financial Economics, 3 pp. 13151360.

Jukes, P., 1990. A shout in the street: An excursion into the modern city. Berkeley, CA: University of California Press.

Kelton, A. S. and Y. Yang, 2008. "The Impact of Corporate Governance on Internet Financial Reporting", Journal of Accounting and Public Policy, 27:62-87.

Khoshandam B., 2015a. Saudi Arabia at Crossroads over Syria's Future: Insisting on Arab World or Coalition with Others?, http://www.iranreview.org/content/Documents/ Saudi-Arabia-at-Crossroads-over-Syria-s-Future-Insisting-on-Arab-World-orCoalition-with-Others-.htm

Khoshandam B., 2015b, Solutions for Syria Crisis at the End of 2015, http://www.iranreview.org/content/Documents/Solutions-for-Syria-Crisis-at-the-Endof-2015.htm

Kohli, A. K., and B. J. Jaworski 1990, Market-orientation: The Construct Research Propositions, and Managerial Implications, Journal of Marketing, Vol. 54, No. (2), pp. 01-18

Leverett F., Leverett H.M. 2015, Saudi Arabia's Yemen Offensive, Iran's "Proxy" Strategy, and the Middle East's New "Cold War", "The World Financial Review" May-June, http://goingtotehran.com/wp-content/uploads/2012/12/TWFR-MayJun2015-Sa udiArabias-Yemen-Offensive-Irans-Proxy-Strategy-and-Mid.Easts-new-cold-war. pdf.

Lipman L. Keith, Lipman D. Frederick, 2006. Corporate Governance Best Practices Strategies for Public, Private and Not-For-Profit Organizations, New jersey : John Wiley \& Sons, Inc.

Lyotard, J.-F., 1984, The Postmodern Condition: A Report on Knowledge, Geoff Bennington and Brian Massumi (trans.), Minneapolis: University of Minnesota Press.

McKendall, Marie., Carol Sánchez, and Paul Sicilian, 1999. Corporate Governance And Corporate Illegality: The Effects Of Board Structure On Environmental Violations. The International Journal of Organizational Analysis. Vol. 7. Iss: 3, pp.201 - 223.

Miller, D., 1987. Material culture and mass consumption. Cambridge, MA: Blackwell.

Miyoshi, M. and H.D. Harootunian (eds.), 1989. Postmodernism and Japan. Durham, NC: Duke University Press.

Mourrain, J.A.P., 1989. The hypermodern commodity form: The case of wine. In: T.L. Childers et al. (eds.), Marketing theory and practice. 318-322. Chicago, IL: American Marketing Asssociation.

Newell, Roberto and Gregory Wilson. 2002. Corporate Governance: A premium for good governance. The Mckinsey Quarterly. Number 3, p.20-23.

Ogilvy, J., 1990. This postmodern business. Marketing and Research Today 18 (Feb.), 4-22.

Parry R. 2015, America's Stolen Narrative: From Washington and Madison to Nixon, Reagan and the Bushes to Obama, The Media Consortium, Austin.

Pemerintah RI, 2010. Undang-undang Nomor 19 Tahun 2003 tentang BUMN. Jakarat: Kementerian Hum dan Ham RI.

Pemerintah RI, Kementerian Negara BUMN, 2015. Buku Profile \& Performance BUMN: Rencana Strategis Kementerian BUMN 2014-1019. Jakarta. 
Peters, G.F., and Romi. A.M., 2012.”The Effect of Corporate Governance on Voluntary Risk Disclosures: Evidence from Greenhouse Gas Emission Reporting", Conference and workshop at the 2010 American Accounting Association Annual Conference, Portland State University's 5th International Conference on Business and Sustainability, Indiana University, Texas Christian Univesity, and the University of Kansas.

Phillips, Robert, 2003. Stakeholder Theory and Organizational Ethics, Berrett-Koehler.

Political \& Economic Risk Concultacy. 2015. Asian Intelligence: Perceptions of Corruption in Asia, the US and Australia http://www.asiarisk.com/subscribe/ exsum1.pdf [diakses $2 / 10 / 2015]$

Rosenau, P., 1992. Postmodernism and the social sciences: Insights, inroads, and intrusions. Princeton, NJ: Princeton University Press.

Scott, L.M., 1992. Playing with pictures: Postmodernism, post-structuralism, and advertising. In: J.F. Sherry, Jr. and B. Sternthal (eds.), Advances in Consumer Research, XIX, 596-612. Provo, UT: Association for Consumer Research.

Sherry, J.F., Jr., 1990. Postmodern alternatives: The interpretive turn in consumer research. In: H. Kassarjian and T. Robertson (eds.), Handbook of consumer research, 548591. Englewood Cliffs, NJ: Prentice Hall.

Solomon, Jill. 2007. Corporate Governance and Accountability. $2^{\text {nd }}$ Edition. England: John Wiley and Sons, Ltd.

Suprayitno, Khomsiyah, Sedarnawati Yasni, Darmawati, dan Aries Susanty, 2005. Internalisasi Good Corporate Governance dalam Proses Bisnis. Jakarta: The Indonesian Institut for Corporate Governance bekerjasama dengan Dankos dan Bank Madiri.

Taliento Marco., 2007. The Role and The Ambit of Corporate Governance and Risk Control Frame, Journal of American Academy of Business Cambridge, n. 11.

Taylor, Victor E., and Winquist, Charles E., 2001, Encyclopedia of Postmodernism, London: Routledge.

Vardi Y., Wiener Y., Misbehavior in Organizations: A Motivational Framework, Organization Science, n.7, 1996.

Vattimo, Gianni, 1988, The End of Modernity: Nihilism and Hermeneutics in Postmodern Culture, Jon R. Snyder (trans.), Baltimore: Johns Hopkins University Press.

Venkatesh, Alladi, John F. Sherry, Jr. b and A. Fuat Frrat. 1993. Postmodernism and the marketing lmaglnar. North-Holland. Intern. J. of Research in Marketing 10 pp. 215223

Venkatesh, Alladi., 1989. Modernity and postmodernity: A synthesis or antithesis. In: T.L. Childers et al. (eds.), Marketing theory and application, 99-104. Chicago, IL: American Marketing Association.

Venkatesh, Alladi., 1990. Changing consumption patterns. In: R. Kling, S. Olin and M. Poster (eds.), Postsuburban California: The transformation of Orange County since World War II, 142-164. Berkeley, CA, University of California Press.

Venkatesh, Alladi., 1992. Postmodernism, consumer culture and the society of the spectacle. In: J.F. Sherry Jr. and B. Sternthal (eds.), Advances in Consumer Research, XIX, 199202. Provo, UT: Association for Consumer Research.

Wernick, A., 1991. Promotional culture: Advertising, ideology and symbolic expression. Newbury, CA: Sage.

Wittgenstein, Ludwig, 1953, Philosophical Investigations, G.E.M. Anscombe (trans.), New York: Macmillan. 
Zarkasyi, Wahyudin 2008. Good Corporate Governance: pada badan usaha Manufaktur, Perbangkan, dan jasa Keuangan Lainnya. Bandung: Alfabeta. 